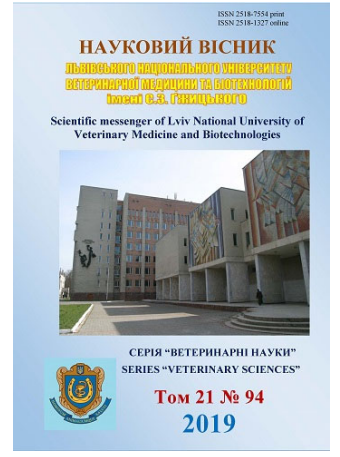

\section{Науковий вісник Яьвівського національного університету ветеринарної медицини та біотехнологій імені С.3. Гжицького.}

\author{
Серія: Ветеринарні науки
}

\section{Scientific Messenger of Lviv National University of Veterinary Medicine and Biotechnologies. Series: Veterinary sciences}

ISSN 2518-7554 print ISSN 2518-1327 online doi: $10.32718 /$ nvlvet 9430

http://nvlvet.com.ua

\title{
Influence of $B$. bovis hairworms on biochemical parameters of blood of patients with bovicolosis of calves
}

\author{
A.M. Shevchenko \\ PE “TORES-N”, Brovary, Kyiv region, Ukraine
}

Article info

Received 26.04.2019

Received in revised form 27.05.2019

Accepted 28.05.2019

PE “TORES-N", Gagarina str., 16, Brovary, Kyiv region, 07400 ,

Ukraine.

Tel.: +38-050-310-16-2

E-mail: an_shevch@rambler.ru

\begin{abstract}
Shevchenko, A.M. (2019). Influence of B. bovis hairworms on biochemical parameters of blood of patients with bovicolosis of calves. Scientific Messenger of Lviv National University of Veterinary Medicine and Biotechnologies. Series: Veterinary sciences, 21(94), 163-168. doi: $10.32718 /$ nvlvet 9430
\end{abstract}

The purpose of the work was to identify the features of the pathological process and changes in the main indicators of blood of cattle for the damage by its hairworms B. bovis. Scientific researches were conducted in the conditions of the Ploskivske BPPZ of the Brovarsky District of the Kyiv Region and the Laboratory of Biochemical Research of the National Cancer Institute. To do this, two groups of young cattle, black-and-white breeds up to one year old with 7 heads in each, were created. The experimental group included calves spontaneously invasive with hairworms. The control group was free of animal parasites. For this, they were previously, in two months, subjected to two-fold treatment with Insecticide Tactics (MSD, the Netherlands). Selected animals on the principle of analogues. All calves were in the same sanitary and hygienic conditions and received the same feed according to the diet. It was found that the glucose content in a sick young bovine animal was $6.25 \%(P<0.5)$ higher than that in calf-free calves. There was a probable difference in the level of urea in the blood of animals, where the average level in the infected calves was $12.69 \%(P<0.001)$ higher than in the control animals. The tendency to decrease by $15.31 \%(P<0.5)$ was found in the average values of serum creatinine in calves in sick animals compared with the group of animals that served as controls and were free from parasites. In blood serum, calves infected with hairworms was found a slightly higher $(4.25 \%, P<0.5)$ level of total bilirubin than those found free from parasites. Indicators of serum cholesterol levels in blood serum of experimental animals were within normal limits. However, it was significantly lower by $14.71 \%(P<0.05)$ in animals affected by parasites. The albumin-globulin ratio in our studies in invasive calves was $9.8 \%(P<0.01)$ higher than that of control animals. In experimental calves with clinical manifestations of bovycolous, the average index of alkaline phosphatase content was $17.58 \%(P<0.5)$ lower than its mean value in blood serum free of invasion by parasites of animals. Thus, among the biochemical parameters of serum of blood of invasive calves, a probable increase in urea and albumin to globulin ratios and a decrease in cholesterol was observed, indicating a negative effect of the hairworms on the organism of animals.

Key words: parasitology, hairworms, calves, biochemistry, blood, invasion.

\section{Вплив волосоїдів $B$. bovis на біохімічні показники крові хворих на бовікольоз телят}

\author{
А.М. Шевченко
}

ПП “ТОРЕС-Н”, м. Бровари, Київська обл., Україна

\footnotetext{
Метою роботи було виявлення особливостей патологічного процесу та змін в основних показниках крові великої рогатої худоби за ураження ї̈ волосоїдами В. ьоvіs. Наукові дослідження провели в умовах ДППз “Плосківське” Броварського району Київської області та лабораторії біохімічних досліджень Національного інституту раку. Для цього було створено дві групи молодняку великої рогатої худоби, чорно-рябої породи віком до одного року по 7 голів в кожній. До дослідної групи входили телята, спонтанно інвазовані волосоїдами. У контрольній групі були вільні від паразитів тварини. Для цьього їх попередньо, за два місяці, піддали двократній обробці інсектицидом Тактик (MSD, Нідерланди). Підбирали тварин за принципом аналогів. Всі телята перебували в
} 
однакових санітарно-гігієнічних умовах та отримували однаковий корм згідно з раціоном. Встановлено, щзо вміст глюкози у хворого молодняку великої рогатої худоби був на 6,25\% $(P<0,5)$ вищим, ніж такий у вільних від членистоногих телят. Спостерігалась вірогідна різниия рівня сечовини у крові тварин, де середній ї̈ рівень у інвазованих бовіколами телят був на 12,69\% (Р < 0,001) вищим, ніж у тварин контрольної групи. Тенденцію до зниження на $15,31 \%(P<0,5)$ виявлено у середніх показниках креатиніну сироватки крові хворих телят порівняно з групою тварин, щзо слугували контролем $і$ були вільними від паразитів. У сироватиі крові інвазованих волосоїдами телят виявили дещь вищий (на 4,25\%, $P<0,5)$ рівень загального білірубіну, ніж у вільних від паразитів. Показники рівня холестеролу в сироватці крові дослідних тварин перебували в межах норми. Однак він був вірогідно нижчим на 14,71\% (P<0,05) в уражених паразитами тварин. Коефічієнт альбуміно-глобулінового співвідношення в наших дослідженнях у інвазованих телят був на 9,8\% (P<0,01) вищим, ніж у тварин контрольної групи. У дослідних телят з клінічними проявами бовікольозу середній показник вмісту лужної фосфатази був на 17,58\% $(P<0,5)$ нижчим, ніж ї̈ середній показник у сироватці крові вільних від інвазії паразитами тварин. Таким чином, серед біохімічних показників сироватки крові інвазованих телят спостерігали вірогідне збільшення показників сечовини і співвідношення альбумінів до глобулінів та зниження рівня холестеролу, щзо свідчило про негативний вплив волосоїдів на організм тварин.

Ключові слова: паразитологія, волосоїди, телята, біохімія, кров, інвазія.

\section{Вступ}

Актуальність теми: Підвищення ефективності сільськогосподарського виробництва залишається одним із пріоритетних завдань, спрямованих на поліпшення економіки нашої держави (Vyniarska et al., 2014). Однією з причин зниження продуктивності великої рогатої худоби є спалахи хвороб різної етіології, у тому числі паразитарної (Jatusevich, 2006).

При цьому негативний вплив паразитів на організм хазяїна характеризується комплексним проявом механічної дії збудника, його трофічної поведінки, токсичним ефектом, здатністю до інокуляції збудників вторинної інфекції та імунодепресії (Kondakova, 2008; Maljutina, 2008).

Так, паразитуючи на тваринах, волосоїди злущують і заковтують епідермальні клітини (L'Hostis \& Seegers, 2002). Муха St. calcitrans тертям хоботка об шкіру “зіскоблює” епідерміс, як облігатний гематофаг, вона живиться кров’ю, виділяє отруйну слину, що закономірно спричиняє розвиток місцевого алергічного запалення. Гнус, окрім кровоссання, при масовому нападі, настирливо набиваючись в ніс, очі та вуха тварин, може призвести до їхньої загибелі внаслідок задухи (Kolesnikov, 2013). Укуси самок гедзів, мокреців і москітів досить болючі, що пов'язано або 3 будовою ротового апарату комах, або дією їхньої отруйної слини (Halatiuk, 2009). Тому поява цих комах на пасовищі викликає у тварин сильне занепокоєння.

Закономірним етапом патогенезу за ентомозів є зниження природних захисних властивостей шкіри хворої худоби. Внаслідок активної життєдіяльності ектопаразитів, в т. ч. B. bovis і H. eurysternus, у хворої худоби розвивається постійний свербіж, виникають різного роду дерматити, на шкірі утворюються вологі плішини, екзематозні ураження, випадає шерсть (Jatusevich, 2006). Також у тварин за бовікольозу та сифункулятозу посилюється тепловіддача та підвищується вологість уражених ділянок, що сприяє розвитку різного роду шкірних інфекцій та простудних захворювань.

Інтенсивна агресія постійних або тимчасових комах-паразитів спричинює розвиток стресу у тваринхазяїв, ослаблює резистентність організму (Horzheiev, 1999). Тварини, які були уражені постійними ектопаразитами або стали об'єктом масового нападу гнусу чи зоофільних мух, спочатку проявляють знервованість, навіть агресивність (особливо бугаї-плідники). Надалі, якщо проблема не зникає, хвора худоба втрачає апетит і помітно виснажується. У лактуючих корів зменшується жирність молока і удійність (до 25-50\% добового надою), можливе повне припинення лактації. В інвазованих тільних корів трапляються аборти, залежування і патології отелення (Sivkov, 2001). Молодняк на відгодівлі втрачає темпи приростів маси тіла на 18-40\% (Horzheiev, 1999).

Хронічні моно- та асоційовані інвазії викликають і суттєві порушення обміну речовин в організмі хворих тварин (Jakubovskij, 1999; Safiullin, 2002). В ураженої худоби розвивається анемія (кількість еритроцитів при гіперінвазії сягає не вище ніж 5,0-5,6 Г/л, а вміст гемоглобіну зменшується до 70 г/л), у сироватці крові знижується вміст альбумінів при різкому збільшенні у-глобулінів, що вказує на токсичні процеси в організмі хворої тварини (Gerke \& Gerke, 2002).

Значна інтенсивність інвазії волосоїдами та вошами може бути ознакою іншої основної патології. Наприклад, за мікроелементозів у ослаблених тварин на декілька тижнів може затримуватися весняна линька, що створює для паразитів додаткові сприятливі умови (Mock, 1997).

У живому організмі кров відіграє першорядну роль, виконуючи транспортну, трофічну функції, доставляє до клітин органів тіла поживні речовини і кисень, видаляє продукти обміну та вуглекислоту. Через кров забезпечуються гормональна регуляція захисних функцій та рівновага електролітів в організмі (Karamaev et al., 2005).

Необхідною умовою нормального існування організму, його органів і тканин є сталість складу крові гомеостаз. Різні порушення життєдіяльності органів і тканин впливають на склад крові, а зміна складу крові своєю чергою, відбивається на життєдіяльності органів і тканин. Кров надзвичайно тонко реагує на різні патологічні процеси, що відбуваються в організмі, й нерідко за зміною кількості і складових елементів крові можна визначити характер патологічного процесу (Minzhasov et al., 2013).

Таким чином, різнобічне дослідження морфологічного та біохімічного складу крові має велике діагностичне значення, оскільки допомагає фахівцю грамотно і вірогідно визначити загальний стан організму тварини, пояснити кореляцію між показниками, про- 
гнозувати результат захворювання, коригувати терапію, вивчати вплив тих чи інших лікарських засобів.

Мета і завдання дослідження. Метою нашої роботи було виявлення особливостей патологічного процесу та змін в основних показниках крові великої рогатої худоби за ураження iї волосоїдами $B$. bovis.

\section{Матеріал і методи досліджень}

Наукові дослідження провели в умовах ДППЗ “Плосківське” Броварського району Київської області та лабораторії біохімічних досліджень Національного інституту раку.

Для цього було створено дві групи молодняку великої рогатої худоби, чорно-рябої породи віком до одного року по 7 голів в кожній. До дослідної групи входили телята, спонтанно інвазовані волосоїдами. У контрольній групі були вільні від паразитів тварини. Для цього їх попередньо, за два місяці, піддали двократній обробці інсектицидом Тактик (MSD, Нідерланди). Підбирали тварин за принципом аналогів. Всі телята перебували в однакових санітарно-гігієнічних умовах та отримували однаковий корм згідно з раціоном.

У телят обох груп ознак хвороб з проявами патологій респіраторного чи шлунково-кишкового трактів не виявляли.

Кров у тварин відбирали з яремної вени до ранкової годівлі у стерильні пробірки з дотриманням правил асептики й антисептики (Karput' et al., 2010).

Біохімічні дослідження проводилися 3 використанням автоматичного біохімічного аналізатора Vitros-250 виробництва США із застосуванням набору реактивів згідно 3 інструкцією. В сироватці крові дослідних і контрольних тварин визначали показники загального білка, альбуміну, глюкози, сечовини, загального білірубіну, холестеролу, креатиніну, коефіцієнту альбуміно-глобулінового співвідношення, білкових фракцій, натрію, калію, хлоридів, кальцію, фосфору, амілази, лужної фосфатази, АсАТ, АлАТ, співвідношення АлАТ/АсАТ.

Дослідження проводили відповідно до вимог “Європейської конвенції про захист хребетних тварин, які використовуються 3 експериментальною та іншою науковою метою" (Страсбург, 1986).

\section{Результати та їх обговорення}

Результати біохімічних досліджень сироватки крові молодняку великої рогатої худоби, вільного від ектопаразитів та інтенсивно ураженого волосоїдами, наведено у табл 1.

Глюкоза - легкодоступне джерело енергії для клітин. Її рівень в сироватці крові тварин обох груп перебував у межах норми (за Н.М. Мотузко та ін., 2008) (Rusak \& Chala, 2016). При цьому показник вмісту глюкози у хворого молодняку великої рогатої худоби був на $6,25 \%(\mathrm{P}<0,5)$ вищим, ніж такий у вільних від членистоногих телят.
Сечовина - продукт обміну нуклеїнових кислот, який виводиться 3 організму через нирки. У наших дослідженнях спостерігалась вірогідна різниця значень цього показника, де середній ії рівень у інвазованих бовіколами телят був на $12,69 \%$ ( $<<0,001)$ вищим, ніж у тварин контрольної групи та був за межами норми.

\section{Таблиця 1}

Біохімічні показники сироватки крові телят, уражених волосоїдами $(\mathrm{M} \pm \mathrm{m}, \mathrm{n}=7)$

\begin{tabular}{lrc}
\hline \multicolumn{1}{c}{ Показник } & \multicolumn{2}{c}{ Група тварин } \\
\cline { 2 - 3 } & контрольна & \multicolumn{1}{c}{ дослідна } \\
\hline Глюкоза, ммоль/л & $3,2 \pm 0,13$ & $3,3 \pm 0,16$ \\
Сечовина, ммоль/л & $6,3 \pm 0,04$ & $7,1 \pm 0,06^{* *}$ \\
Креатинін, мкмоль/л & $99,9 \pm 2,83$ & $84,6 \pm 6,44$ \\
Заг. білірубін, мкмоль/л & $4,7 \pm 0,59$ & $4,9 \pm 0,57$ \\
Натрій, ммоль/л & $144,6 \pm 2,37$ & $144,8 \pm 2,48$ \\
Калій, ммоль/л & $4,1 \pm 0,13$ & $4,2 \pm 0,10$ \\
Хлориди, ммоль/л & $94,9 \pm 1,74$ & $96,9 \pm 1,61$ \\
Амілаза, U/L & $3,0 \pm 0,00$ & $3,0 \pm 0,00$ \\
Кальцій, ммоль/л & $2,3 \pm 0,04$ & $2,4 \pm 0,04$ \\
Фосфор, ммоль/л & $2,8 \pm 0,14$ & $2,7 \pm 0,07$ \\
Холестерол, ммоль/л & $3,4 \pm 0,19$ & $2,9 \pm 0,17 *$ \\
Альбумін, г/л & $24,0 \pm 0,76$ & $23,3 \pm 0,78$ \\
Альбумін/Глобуліни & $0,51 \pm 0,01$ & $0,56 \pm 0,03 * *$ \\
\hline \hline
\end{tabular}

Примітка: *- ${ }^{*}<0,05 ; * *-\mathrm{P}<0,01$ порівняно з показниками контрольної групи тварин

Тенденцію до зниження на 15,31\% (Р < 0,5) виявлено у середніх показниках креатиніну сироватки крові хворих телят порівняно з групою тварин, що слугували контролем і були вільними від паразитів.

У сироватці крові інвазованих волосоїдами телят виявили дещо вищий (на 4,25\%, Р < 0,5) рівень загального білірубіну, ніж у вільних від паразитів.

Разом 3 аніонами натрій є основним осмотичним компонентом плазми, що істотно впливає на розподіл води в організмі. У наших біохімічних дослідженнях концентрація натрію істотно не відрізнялась у всіх тварин, що піддавались обстеженню.

Рівень калію у зразках сироватки крові телят дослідної групи був вищим на $2,4 \%$ (Р < 0,5), ніж у тварин, що слугували контролем.

Хлориди - основні аніони позаклітинної рідини. Їхній вміст у сироватці крові дослідного молодняка великої рогатої худоби був на $2,10 \%(\mathrm{P}<0,5)$ вищим, ніж у телят контрольної групи.

Амілаза сироватки крові, показник деструкції підшлункової і слинних залоз, у наших дослідженнях був у межах норми та за своїми середніми значеннями показники не відрізнялись ні в одній з досліджуваних проб сироваток крові.

Значення кальцію і фосфору в годівлі сільськогосподарських тварин $є$ загальновизнаним. Як нестача, так і надлишок їх в раціоні призводять до порушення обміну речовин, яке супроводжується зниженням продуктивності, порушенням відтворення, захворюваннями тварин і погіршенням використання кормів.

Як показали результати наших досліджень, рівень кальцію у сироватці крові телят, інвазованих B. bovis, 
був на 4,34\% (P < 0,5) вищим, ніж у тварин, вільних від паразитів.

Інша картина спостерігалась в показниках фосфорного обміну. Вміст фософру у сироватці крові хворих тварин був на $3,57 \%(\mathrm{P}<0,5)$ нижчим, ніж у телят, що слугували контролем.

Холестерол - вторинний високомолекулярний одноатомний спирт, входить до складу протоплазми i синтезується в печінці. Показники рівня холестеролу в сироватці крові дослідних тварин перебували в межах норми. Однак він був вірогідно нижчим на $14,71 \%(\mathrm{P}<0,05)$ в уражених паразитами тварин.

За результатами наших біохімічних тестів показник альбуміну в обох групах був нижчим за норму. При цьому в сироватці крові телят дослідної групи рівень вмісту альбуміну був нижчим на 2,92\% $(\mathrm{P}<0,5)$, ніж у тих, що служили контролем.

Коефіцієнт альбуміно-глобулінового співвідношення в наших дослідженнях у інвазованих телят був на 9,8\% (Р < 0,01) вищим, ніж у тварин контрольної групи.

Вміст загального білка в сироватці крові є важливим показником, що характеризує рівень метаболізму в організмі тварин. Білки є будівельним матеріалом для клітин тканин організму, активно беруть участь в утворенні різних видів продукції (Buslovskaja, 2003; Lavryshyn \& Gutyj, 2019).

Так, у наших дослідженнях в інвазованих волосоїдами телят спостерігалось зниження нижче норми рівня загального білка в сироватці крові на 5,18\% $(\mathrm{P}<0,5)$ (табл. 2).

\section{Таблиця 2}

Біохімічні показники активності ферментів у телят $(\mathrm{M} \pm \mathrm{m}, \mathrm{n}=7), \mathrm{P}<0,5$

\begin{tabular}{lcc}
\hline \multicolumn{1}{c}{ Показник } & \multicolumn{2}{c}{ Група тварин } \\
\cline { 2 - 3 } контрольна & дослідна \\
\hline Заг. білок, г/л & $69,4 \pm 2,04$ & $65,8 \pm 1,88$ \\
АсАТ, U/L & $87,9 \pm 3,13$ & $88,0 \pm 2,89$ \\
АлАТ, U/L & $48,7 \pm 3,94$ & $48,9 \pm 2,35$ \\
Співвідношення & $1: 1,80$ & $1: 1,79$ \\
АлАТ/АсАТ & $189,4 \pm 14,87$ & $156,1 \pm 15,15$ \\
Лужна фосфатаза, U/L & & \\
\hline
\end{tabular}

Обмін речовин в організмі складається з сукупності безлічі хімічних реакцій; їх перебіг здійснюється за допомогою біологічних каталізаторів-ферментів, одним 3 яких є клас трансфераз, що каталізують реакції гідролітичного розщеплення внутрішньомолекулярних зв'язків (Khariv et al., 2016; Gutyj et al., 2017).

У наших дослідженнях суттєвої різниці в активності ферментів аспартатамінотрансферази (АсАТ) i аланінамінотрансферази (АлАТ) у сироватці крові молодняку великої рогатої худоби обох груп не виявлено.

Незначне коливання в бік підвищення на $0,16 \%$ $(\mathrm{P}<0,5)$ виявлено у середніх показниках АсАТ сироватки крові телят, уражених волосоїдами, порівняно 3 аналогічним показником у групі тварин, вільних від ектопаразитів.
Незначне відхилення від середнього значення АлАТ спостерігали у сироватці крові хворих тварин порівняно з кров'ю тварин, що служили контролем.

Лужна фосфатаза - фермент, що утворюється в кістковій тканині, печінці, слизовій оболонці кишечнику, плаценті, легенях.

В результаті біохімічних досліджень виявлено значну різницю цього показника у тварин контрольної та дослідної груп. Так, у дослідних телят з клінічними проявами бовікольозу середній показник вмісту лужної фосфатази був на $17,58 \%(\mathrm{P}<0,5)$ нижчим, ніж іiі середній показник у сироватці крові вільних від інвазії паразитами тварин.

На нашу думку, незначна, в фізіологічних межах гіпопротеїнемія і гіпоальбумінемія за відсутності виражених патологічних процесів, спостерігається за недостатнього надходження білків та амінокислот 3 кормом, а також мобілізації білків як джерел енергії (Levchenko, 2002). Крім того, появу гіпопротеїнемії можна пов'язати 3 напруженням процесів адаптації, безпосередньо зі зниженням рівня білкового обміну, що збігається з повідомленнями А.Ю. Ковтуненко (Kovtunenko, 2012).

Тенденції $(\mathrm{P}<0,5)$ до прояву гіперглікемії, гіперхлоремії, гіперкальціємії, підвищення рівня натрію, калію узгоджуються 3 літературними даними (Buslovskaja, 2003) щодо ознак неспецифічної реакції організму, спрямованої на формування підвищеної резистентності та адаптації у відповідь на несприятливі впливи зовнішнього середовища.

Сечовина утворюється в гепатоцитах і $є$ основним кінцевим азотовмістним продуктом розпаду білків в організмі. Синтез сечовини $є$ головним способом знешкодження токсичного аміаку, що утворюється в тканинах і шлунково-кишковому каналі, а також виведення його з організму через нирки з сечею. Концентрація сечовини в крові залежить передусім від стану видільної функції нирок. Підвищення пї концентрації спостерігається при нирковій недостатності і обтурації сечовивідних шляхів, а також за низького засвоєння кормових протеїнів (Anhielski et al., 1998).

Отримані нами дані про значне вірогідне підвищення сечовини на $12,69 \%(\mathrm{P}<0,001)$ у інвазованих телят при зниженні рівня альбумінів свідчили, на нашу думку, про незбалансованість раціону за енергопротеїновим співвідношенням.

Тенденція до зниження рівня креатиніну в наших дослідах також була ознакою недостатнього рівня енергозабезпечення м'язової тканини. Це підтверджує А.Ю. Ковтуненко (2012), вказуючи на енергодефіцит, що розвивається внаслідок неможливості підтримання гомеостазу в умовах, що супроводжуються стресовими явищами (Kovtunenko, 2012).

Вірогідне зниження рівня холестеролу в сироватці крові, на нашу думку, вказує на загальну недостатню годівлю та свідчить про зниження рівня обмінних процесів в організмі, а також виникає внаслідок мобілізації ліпідів як джерела енергії, компенсуючи напруженість інших видів обміну. При цьому перехід енергетичного обміну з вуглеводного типу до ліпідно- 
го характеризує перехід до стадії резистентності стреcy (Kushnerova et al., 2005).

Вірогідне збільшення коефіцієнту альбуміноглобулінового співвідношення у телят дослідної групи може вказувати на адаптивні процеси, які пов'язані 3 віковими фізіологічними змінами, сезонним зниженням температури довкілля та подразнюючим фактором - волосоїдами, що частково узгоджується 3 дослідженнями Ю.В. Ітесь (Itjes', 2001).

Таким чином, серед біохімічних показників сироватки крові інвазованих телят спостерігали вірогідне збільшення показників сечовини і співвідношення альбумінів до глобулінів та зниження рівня холестеролу, що свідчило про негативний вплив волосоїдів на організм тварин.

\section{Висновки}

1. Ураження волосоїдами Bovicola bovis призводить до порушення обмінного стазу у телят.

2. У сироватці крові інвазованих телят встановлено підвищення вмісту сечовини на $12,69 \%$ ( $>0,01)$, коефіцієнту альбуміно-глобулінового співвідношення на 9,8\% (P < 0,01) та зниження вмісту холестеролу на $14,71 \%(\mathrm{P}<0,05)$ порівняно з контролем.

Перспективи подальших досліджень. В наступних дослідженнях планується провести визначення впливу волосоїдів B. bovis на продуктивність великої рогатої худоби.

\section{References}

Anhielski, S., Dominichak, M., \& Yakubovski, Z. (1998). Klinichna biokhimiia. Sopot (in Ukrainian).

Buslovskaja, L.K. (2003). Jenergeticheskij obmen i kislotno-shhelochnoj balans u sel'skohozjajstvennyh zhivot-nyh pri adaptacii k stressoram. Belgorod: BelGU (in Russian).

Byford, R.L., Craig, M.E., \& Crosby, B.L. (1992). A review of ectoparasites and their effect on cattle production. Journal Animal Scence, 70(2), 597-602. doi: $10.2527 / 1992.702597 x$.

Gerke, V.S., \& Gerke, A.N. (2002). Nekotorye aspekty obshhej reakcii organizma pri jektoparazitozah. Aktual'-nye problemy veterinarnoj mediciny "Zoosfera": mat. konf., posv. 300-letiju SanktPeterburga, 70-73 (in Russian).

Gutyj, B., Leskiv, K., Shcherbatyy, A., Pritsak, V., Fedorovych, V., Fedorovych, O., Rusyn, V., \& Kolomiiets, I. (2017). The influence of Metisevit on biochemical and morphological indicators of blood of piglets under nitrate loading. Regulatory Mechanisms in Biosystems, 8(3), 427-432. doi: 10.15421/021766.

Gutyj, B., Martyshchuk, T., Bushueva, I., Semeniv, B., Parchenko, V., Kaplaushenko, A., Magrelo, N., Hirkovyy, A., Musiy, L., \& Murska, S. (2017). Morphological and biochemical indicators of blood of rats poisoned by carbon tetrachloride and subject to action of liposomal preparation. Regulatory Mechanisms in Biosystems, 8(2), 304-309. doi: 10.15421/021748.
Halatiuk, O.Ye. (2009). Profilaktyka ta likuvannia zaraznykh khvorob konei. Zhytomyr: Ruta, 242-246 (in Ukrainian).

Horzheiev, V.M. (1999). Stan ta perspektyvy borotby z hipodermatozom velykoi rohatoi khudoby. Veterynarna medytsyna Ukrainy, 10, 26-27 (in Ukrainian).

Itjes' Ju.V. (2001). Biohimicheskij status krupnogo rogatogo skota raznogo vozrasta. Laboratorium (in Russian).

Jakubovskij, M.V. (1999). Jekonomicheskaja effektivnost' profilaktiki parazitarnyh boleznej zhivotnyh. Veterinarnye novosti, 9, 7-9 (in Russian).

Jatusevich, A.I. (2006). Arahnojentomozy domashnih zhvachnyh i odnokopytnyh : monografija. Vitebsk : VGAVM (in Russian).

Karamaev, V.B., Marchenko, V.A., Vasilenko, Ju.A., \& Saitov, V.R. (2005). Jepizootologicheskaja situacija po nekotorym parazitozam sel'skohozjajstvennyh zhivotnyh v Respub-like Altaj. Parazitologicheskie iss-ledovanija v Sibiri i na Dal'nem Vostoke : sb. nauch. rab. Novosibirsk, 81-83 (in Russian).

Karput', I.M., Kurdeko, A.P., \& Abramova, S.S. (2010). Vnutrennie nezaraznye bolezni zhivotnyh: praktikum. Minsk: IVC Minfina (in Russian).

Khariv, M.I., Hutyi, B.V., Vishchur, O.I., \& Solovodzinska, I.Ye. (2016). Funktsionalnyi stan pechinky u shchuriv za umov oksydatsiinoho stresu ta dii liposomalnoho preparatu. Nauk. zap. Ternop. nats. ped. un-tu. Ser. Biol., 2(66), 76-84 (in Ukrainian).

Kolesnikov, V.I. (2013). Insekticidnaja i repellentnaja jeffektivnost' novogo preparata del'cid protiv krovososushhih dvukrylyh nasekomyh. Sb. nauch. tr. Stavropol'skogo nauch.-issled. instituta kormoproizvodstva, 6(1), 234-238 (in Russian).

Kondakova, L.V. (2008). Fauna jektoparazitov sel'skohozjajstvennyh zhivotnyh i ptic. Agrarnyj vestnik Urala, 1(43), 60-61 (in Russian).

Kovtunenko, A.Ju. (2012). Adaptacija korov k vozdejstviju nizkih temperatur. Sovremennye problemy nauki i obrazovanija, 4. http://www.scienceeducation.ru/ru/article/view?id=6709 (in Russian).

Kushnerova, N.F., Sprygin, V.G., \& Fomenko, S.E. (2005). Vlijanie stressa na sostojanie lipidnogo i uglevodnogo obmena pecheni, profilaktika. Gigiena i sanitarija, 5, 17-21 (in Russian).

Lavryshyn, Y.Y., \& Gutyj, B.V. (2019). Protein synthesize function of bulls liver at experimental chronic cadmium toxicity. Scientific Messenger of Lviv National University of Veterinary Medicine and Biotechnologies. Series: Veterinary sciences, 21(94), 92-96. doi: 10.32718/nvlvet9417.

Levchenko, V.I. (2002). Doslidzhennia krovi tvaryn ta klinichna interpretatsiia otrymanykh rezultativ. Bila Tserkva: BHU (in Ukrainian).

L'Hostis, M., \& Seegers, H. (2002). Tick-born parasitic in cattle: current knowledge and prospective risk analysis related to the ongoing evolution in French cattle farming systems. Veterinary Research, 33(5), 599-611. https://www.ncbi.nlm.nih.gov/pubmed/12387492. 
Maljutina, T.A. (2008). Vzaimootnoshenija v sisteme parazit - hozjain: biohimicheskie i fiziologicheskie aspekty adaptacii (retrospektivnyj obzor). Rossijskij parazitologicheskij zhurnal, 1, 24-40. https://elibrary.ru/item.asp?id=11769490 (in Russian).

Minzhasov, K.I., Muhametova, V.D., \& Aubakirova, A.K. (2013). Biohimicheskij skrining krovi korov s narushe-nijami vosproizvoditel'noj funkcii. Sel'skoe, lesnoe i vodnoe hozjajstvo, 3, 3. http://agro.snauka.ru/2013/03/935 (in Russian).

Mock, D.E. (1997). Managing insect problems on beef cattle. Journal of Kansas State University, 9, 24.

Rusak, V.S., \& Chala, I.V. (2016). Klinichna otsinka biokhimichnykh, morfolohichnykh pokaznykiv krovi ta sechi tvaryn. Zhytomyr : Polissia (in Ukrainian).
Safiullin, R.T. (2002). Jekonomicheskoe znachenie parazitarnyh boleznej krupnogo rogatogo skota. Teorija i praktika bor'by s parazitarnymi boleznjami (zoonozy): mat. dokl. nauch. konf. Moskva, 3, 297-299 (in Russian).

Sivkov, G.S. (2001). Problemy zashhity zhivotnyh ot paraziticheskih chlenistonogih v Sibiri. Problemy jentomologii i arahnologii: sb. nauch tr. VNIIVJeA. Ekaterinburg: Putived, 42, 3-9 (in Russian).

Vyniarska, A.V., Stybel, V.V., Podoliak, V.P., \& Nalychnyk, Ya.A. (2014). Veterynarnyi suprovid u koniarstvi. Naukovo-tekhnichnyi biuleten, 111, 272277. http://nbuv.gov.ua/UJRN/Ntb_2014_111_40 (in Ukrainian). 